\title{
Coloboma of macula-brachydactyly type B syndrome
}

INSERM

\section{Source}

INSERM. (1999). Orphanet: an online rare disease and orphan drug data base. Coloboma of macula-brachydactyly type B syndrome. ORPHA:1471

Coloboma of macula - brachydactyly type B or Sorsby syndrome is a malformation syndrome characterized by the combination of bilateral coloboma of macula with horizontal pendular nystagmus and severe visual loss, and brachydactyly type B (see these terms). The hand and feet defects comprise shortening of the middle and terminal phalanges of the second to fifth digits, hypoplastic or absent nails (congenital anonychia; see this term), broad or bifid thumbs and halluces, syndactyly and flexion deformities of the joints of some digits. Coloboma of macula - brachydactyly type B is inherited in a dominant manner. 